Original Research

\title{
Nurses' Individual Characteristics Associated with Five Moments Handwashing Compliance
}

\author{
Maryana Maryana and Rima Berti Anggraini \\ STIKES Citra Delima Bangka Belitung, Pangkal Pinang, Indonesia
}

\begin{abstract}
Introduction: The most effective way to control infection is to ensure that hospital staff carry out handwashing according to the protocols. This study aims to determine the characteristics of nursing individuals that affect the compliance of the five moments of handwashing in the hospital inpatient room.

Methods: The method used was a quantitative with a cross-sectional approach. The population was all nurses in five inpatient rooms totalling 84 nurses selected using purposive sampling. The dependent variable was the compliance of nurses' handwashing. The independent variables were the individual characteristics of the nurses, including knowledge, gender, age, attitude, motivation, skin condition, years of service, education, employment status, infrastructure, and type of room. The data were collected using a questionnaire and observation of handwashing compliance. The handwashing observation was based on the hospital guidelines, and the relationship between the variables was analyzed using Chi square and logistic regressions test.

Results: The study indicates that there is a significant relationship between motivation, education, and room type on compliance with the five moments handwashing $(\mathrm{p}<0.05)$. The most dominant factor was type of room, and there is no relationship between gender, age, years of work, skin condition, knowledge, attitude, employment status and infrastructures ( $\mathrm{p}>0.05)$.

Conclusion: It is hoped that nurses can increase self-motivation to wash their hands for five minutes while working, as a form of dedication at work and to protect patients and themselves from nosocomial infections. Besides, hospital management needs to make efforts to increase the motivation of nurses.
\end{abstract}

\section{ARTICLE HISTORY}

Received: October 20, 2020

Accepted: September 11, 2021

\section{KEYWORDS}

five moments; handwashing compliance; nursing implementation

\section{CONTACT}

Maryana Maryana
$\square$ maryana385@yahoo.com
$\triangleq$ STIKES Citra Delima
Bangka Belitung, Pangkal
Pinang, Indonesia

Pinang, Indonesia

Cite this as: Maryana, M \& Anggraini, R., B. (2021). Nursing Individual Characteristics Affecting Five Moments Handwashing Compliance. Jurnal Ners, 16(2). 135-141. doi: http://dx.doi.org/10.20473/jn.v16i2.22399

\section{INTRODUCTION}

The incidence of nosocomial infections is increasing in both developed and developing countries. The cause of nosocomial-infections is mostly transient flora. Microorganisms classified as transient flora are obtained by health workers when they are in direct contact with patients or with a contaminated environment. The source of cross-contamination in hospitals is the transfer of microorganisms from the hands of healthcare workers who make direct contact from one patient to another. The impact of the incidence of infection nosocomial can cause long days of stay, increase resistance to microorganisms, increase the burden of treatment costs, and, the most dangerous, death. One of the components to limit the spread of nosocomial infections is sufficient infection control. The most effective way to control contamination is to ensure that hospital staff perform hand hygiene according to the regulation (Lankford et al., 2003; WHO, 2009).

The Word Health Organization (WHO), a longstanding leading authority in campaigning hand hygiene $(\mathrm{HH})$, urges every country to strengthen infection prevention and control, and appeals for networking with stakeholders to take better action for the prevention of HAIs (Saito, Kilpatrick, \& Pittet, 2018). HAIs are still a substantial burden among infectious diseases, exceeding the burden of other infections such as influenza and tuberculosis (Cassini, Plachouras, Eckmanns, Abu Sin, Blank, Ducomble, \& Suetens, 2016).

Nurses, doctors, and all people involved in patient care must perform infection prevention and control 
(Duerink et al., 2006). Hand hygiene is the most effective simple way and the most cost-reducing approach to nosocomial infections (Hugonnet et al., 2002; Kampf et al., 2009; Sickbert-Bennett et al., 2016; von Lengerke et al., 2017). Nurses are professionals who play a significant role in hospital services and have contact with patients for a longer time, up to 24 hours straight. Thus, nurses have a role in the incidence of nosocomial infections (Nursalam, 2011). Health workers generally know about the importance of washing hands to prevent infections. However, the implementation of handwashing that follows the standard procedure is still low among health workers (Akyol, 2007; Nurbaety et al., 2019). Various previous studies stated that compliance with nurses' handwashing was still low, not reaching 100\% (Jonker \& Othman, 2018; Karuru et al., 2016; Putri et al., 2018; Ratnasari \& Dulakhir, 2016; Umboh et al., 2017 ). Based on previous research, it is known that the individual characteristics of nurses related to handwashing compliance include age, gender, length of work, knowledge, attitudes, motivation, and nurse education (Anugrahwati \& Hakim, 2019; Fauzi et al., 2015; Zainaro \& Laila, 2020).

Based on the description above, this study aims to determine the individual characteristics of nurses that affect the compliance of the five moments handwashing in the inpatient room of Pangkalpinang City with a quantitative approach.

\section{MATERIALS AND METHODS}

This research is a quantitative study with a crosssectional approach. The dependent variable of the study is the nurses' compliance with handwashing in the inpatient room. The independent variables are individual characteristics, including knowledge, gender, age, attitude, motivation, skin conditions, length of work, education, employment status, infrastructure, and type of room. The population of the study were all associated nurses who work in the inpatient room, as many as 98 nurses. A total of 84 implementing nurses as research respondents was obtained using purposive sampling (ICU = 14; PICU = 16; Non-surgical $=27$; Children $=12$; Surgery $=15$ ) with the following inclusion criteria: (1) willing to be respondents, (2) not being assigned to the isolation room during the research. The COVID-19 isolation room was not involved in the research because, when the study was taking place, there were no patients. Thus, they could not estimate washing hands for the five moments.

The procedure in this research began by arranging a permit to a government hospital in Pangkal Pinang City. It was followed by conducting a meeting to equate the perception of the research process. The meeting was performed by hospital infection prevention and control programs (IPC). Four people assisted in the process of data collection. Two students were as research assistants who were in charge of collecting questionnaires and documentation. Two hospital IPC officers were responsible for observing the compliance of nurses' handwashing in the rooms. Researchers also coordinated with all heads of room related to research activities. First, the researchers explained to the respondents about the objectives and procedure of the research and the guarantee of data confidentiality. Nurses willing to sign the informed consent form as research respondents then filled out the questionnaire. The study questionnaire was adopted from previous researchers with modifications. The questionnaire covered the nurse's identity (name, age, gender, latest education, years of service, skin condition), room name, and handwashing infrastructure. The knowledge variable consists of 10 questions about the five moments handwashing and has passed the validity and reliability test. Questionnaire validation and reliability test had been done at RSUP Ir. Soekarno with the number of respondents as many as 20 people. Cronbach's alpha test results obtained knowledge value (0.932), motivation (0.958), attitude (0.969) and were declared reliable. Of the 10 questions and statements, all are declared valid with a calculated $\mathrm{R}$ value $>\mathrm{R}$ table (0.375). Each correct answer is given a value of 1 and 0 if the answer is wrong. The attitude variable includes 10 statements consisting of eight positive statements and two negative statements using a Likert scale. Meanwhile, the motivation variable has 10 statements using a Likert scale. For positive statements, the highest point is 5 in the SS category (strongly agree), while the highest point negative statement is 5 in the STS category (strongly disagree).

The 84 nurses were then observed for the five moments of handwashing compliance in the room by the hospital IPC officers. The observation process was uninformed to the respondents, and only carried out once in 10 days, starting from 22nd to 31rd of August, 2020. Furthermore, each research respondent is given a code, R01 for the first respondent up to R84. The questionnaire files and observation sheets were not accessible other than to the researchers. After data collection was complete, the study continued with data entry. Incomplete nurse data were confirmed to the head of the room concerned. The relationship between individual characteristics and compliance with handwashing was tested using the Chi-square test with a confidence degree of $95 \%$ ( $\alpha=$ $0.05)$. Meanwhile, the relationship between variables was analyzed using the multivariate analysis method using logistic regression test with SPSS version 20 software.

\section{RESULTS}

Based on Table 1, there are 11 characteristic components of individual nurses. The dominance of female gender nurses, age less than 40 years, vocational education, long working period, nonsensitive skin condition, and civil servant status. Knowledge, attitude and motivation have equal value. 
Table 1. Characteristics of Research Respondents

\begin{tabular}{|c|c|c|c|}
\hline $\begin{array}{c}\text { Characteristics of } \\
\text { Respondents }\end{array}$ & $\mathbf{n}$ & $\%$ & Median \\
\hline \multicolumn{4}{|l|}{ Age } \\
\hline$>41$ Years & 13 & 15.5 & \multirow[t]{2}{*}{ - } \\
\hline$\leq 40$ Years & 71 & 84.5 & \\
\hline \multicolumn{4}{|l|}{ Motivation } \\
\hline Low & 35 & 41.7 & \multirow[t]{2}{*}{39.07} \\
\hline High & 49 & 58.3 & \\
\hline \multicolumn{4}{|l|}{ Attitude } \\
\hline Negative & 39 & 44.6 & \multirow[t]{2}{*}{43.67} \\
\hline Positive & 45 & 53.6 & \\
\hline \multicolumn{4}{|l|}{ Knowledge } \\
\hline Fair & 31 & 36.9 & \multirow[t]{2}{*}{9.61} \\
\hline Good & 53 & 63.1 & \\
\hline \multicolumn{4}{|l|}{ Work Period } \\
\hline New & 10 & 11.9 & \multirow{2}{*}{-} \\
\hline Old & 71 & 88.1 & \\
\hline \multicolumn{4}{|l|}{ Infrastructure } \\
\hline Insufficient & 4 & 4.8 & \multirow[t]{2}{*}{ - } \\
\hline Adequate & 80 & 95.2 & \\
\hline \multicolumn{4}{|l|}{ Skin condition } \\
\hline Sensitive & 14 & 16.7 & \multirow[t]{2}{*}{ - } \\
\hline Not Sensitive & 70 & 83.3 & \\
\hline \multicolumn{4}{|l|}{ Education } \\
\hline Vocational Degree & 63 & 75 & \multirow{3}{*}{ - } \\
\hline Academic Degree & 6 & 7.1 & \\
\hline Professional Degree & 15 & 17.9 & \\
\hline \multicolumn{4}{|l|}{ Employment Status } \\
\hline Civil Servant & 63 & 75 & \multirow[t]{2}{*}{-} \\
\hline Contract & 21 & 25 & \\
\hline \multicolumn{4}{|l|}{ Gender } \\
\hline Male & 12 & 14.3 & \multirow[t]{2}{*}{-} \\
\hline Female & 72 & 85.7 & \\
\hline
\end{tabular}

Table 2. Distribution of Respondents' Handwashing

\begin{tabular}{lccc}
\hline \multicolumn{2}{c}{ Handwashing Compliance } & n & \% \\
\hline Noncompliant & & 53 & 63.1 \\
Compliant & Total & 31 & 36.9 \\
& & 84 & 100 \\
\hline
\end{tabular}

Table 3. Percentage Distribution of Respondents' Handwashing by Type of Room

\begin{tabular}{lccccc}
\hline \multirow{2}{*}{$\begin{array}{l}\text { Type of } \\
\text { Room }\end{array}$} & \multicolumn{3}{c}{ Handwashing Compliance } & Total \\
\cline { 2 - 5 } & \multicolumn{2}{c}{ Noncompliant } & \multicolumn{2}{c}{ Compliant } & \multirow{2}{*}{ n } \\
\cline { 2 - 5 } & $\mathbf{n}$ & $\mathbf{\%}$ & $\mathbf{n}$ & $\mathbf{\%}$ & \\
\hline ICU \& PICU & 7 & 23.3 & 23 & 76.7 & 30 \\
Non-surgical & 25 & 92.6 & 2 & 7.4 & 27 \\
Surgery & 12 & 80 & 3 & 20 & 15 \\
Children & 9 & 75 & 3 & 25 & 12 \\
Total & & & & & 84 \\
\hline
\end{tabular}

\section{Handwashing Compliance}

Most of the respondents (63.1\%) in this study did not comply with the five-minute handwashing, as in Table 2 . The room with the highest level of compliance with washing hands was the ICU \& PICU room, while in the normal inpatient room the level of compliance with washing hands was low, as shown in Table 3. While the five most neglected moments are after touching patient surroundings, as in Table 5.

Based on the statistical test in Table 2, there are three variables with $\mathrm{p}$-value $<0.05$, namely motivation, education, and type of room. It shows that the three aspects affect the washing of hands by nurses in the room. Furthermore, the OR value of the motivation variable is 2.986 , meaning that nurses who have high motivation have the opportunity to comply 2.98 times more than nurses with low motivation. Based on the multivariate logistic regression test, the omnibus test section shows a pvalue of $0.0001(<0.05)$, which means that there is an interaction between motivation, education and type of room on compliance with handwashing. Based on Table 6, it can be found that the most dominant variable is the type of room.

\section{DISCUSSION}

Most of the respondents in this study did not comply with washing their hands for five moments. The research found only a small part of the individual characteristics of nurses that affect handwashing compliance, namely education and motivation. New findings from this research are that type of room was known to be significantly related to handwashing compliance, and to be the most dominant factor. The results of this study support previous research reporting that most nurses do not comply with handwashing (Arifin \& Ernawaty, 2019; Karuru et al., 2016; Nurbaety et al., 2019). Handwashing or hand hygiene is a general term that refers to the act of cleansing the hands five times, commonly called five moments. The five moments are: the moment before contact with the patient, before the cleaning procedure or aseptic, after procedures exposing to the body fluids, after contact with patients, and after contact with the area around the patient (WHO, 2009). Permenkes no 27 Tahun 2017, concerning infection prevention and control in health facility services, states that hand hygiene is one of the standard precautions that must be applied routinely in the care of all patients in the hospital.

The hospital as a medical service unit cannot be separated from the activities of treatment and care for patients with various causes, one of which is infection. Infections that occur in health services during treatment and medical procedures after $\geq 48$ hours and after $\leq 30$ days after leaving a health facility are called nosocomial infections or hospital-acquired infections (HAI). According to Petersen et al. (2010), HAI causes a prolonged length of stay, thus harming patients and increasing treatment costs. HAI is a worldwide problem because it is detrimental to patients and hospitals. Lankford et al. (2003) state that one of the components to limit the spread of HAI is to implement infection control. The most effective way to control infection is to ensure that hospital-staff practice hand hygiene following the standard.

Factors related to the compliance level of nurses' handwashing include individual-factors, i.e.: gender, age, facilities, attitudes, length of work (Anugrahwati \& Hakim, 2019; Arifin \& Ernawaty, 2019; Fauzi et al., 2015; Pratama et al., 2016). However, this study gave different results as to which of these factors did not 
Table 4. Five Moment Handwashing by Type of Rooms

\begin{tabular}{llcccc}
\hline \multicolumn{2}{c}{ Five Moment } & & \multicolumn{3}{c}{ Type of Room (\%) } \\
\cline { 3 - 6 } & & ICU \& PICU & Non-Surgical & Surgery & Children \\
\hline Before touching a patient & Noncompliant & 0 & 59.3 & 33.4 & 41.7 \\
Before clean/aseptic procedures & Compliant & 100 & 40.7 & 66.6 & 58.3 \\
& Noncompliant & 0 & 22.3 & 13.4 & 25 \\
After body fluid exposure/risk & Compliant & 100 & 77.7 & 86.6 & 75 \\
After touching a patient & Noncompliant & 0 & 7.5 & 6.7 & 0 \\
After touching the patient's & Compliant & 100 & 92.5 & 93.3 & 100 \\
surroundings & Noncompliant & 0 & 0 & 0 & 0 \\
\hline
\end{tabular}

Table 5. Relationship of Nurses' Individual Characteristics toward Handwashing Compliance

\begin{tabular}{|c|c|c|c|c|c|c|c|c|}
\hline \multirow{3}{*}{$\begin{array}{l}\text { Characteristics of Individual } \\
\text { Respondents }\end{array}$} & \multicolumn{4}{|c|}{ Compliance with Handwashing } & \multirow{2}{*}{\multicolumn{2}{|c|}{ Total }} & \multirow{3}{*}{$\begin{array}{c}\text { OR } \\
(95 \% \mathrm{CI})\end{array}$} & \multirow{3}{*}{$\begin{array}{c}\text { p- } \\
\text { value }\end{array}$} \\
\hline & \multicolumn{2}{|c|}{ Non-compliant } & \multicolumn{2}{|c|}{ Compliant } & & & & \\
\hline & $\mathrm{n}$ & $\%$ & $\mathrm{n}$ & $\%$ & $\mathrm{n}$ & $\%$ & & \\
\hline Age & 7 & 53.8 & 6 & 46.2 & 13 & 100 & 0.643 & 0.537 \\
\hline $\begin{array}{l}>41 \text { Years } \\
\leq 40 \text { Years }\end{array}$ & 46 & 64.8 & 25 & 35.2 & 71 & 100 & $(0.192-2.093)$ & \\
\hline Attitude & 27 & 77.1 & 8 & 22.9 & 35 & 100 & 0.584 & 0.339 \\
\hline $\begin{array}{l}\text { Negative } \\
\text { Positive }\end{array}$ & 26 & 53.1 & 23 & 46.9 & 49 & 100 & $(0.239-1.429)$ & \\
\hline Knowledge & 20 & 64.5 & 11 & 35.3 & 31 & 100 & 1.102 & 1.000 \\
\hline $\begin{array}{l}\text { Fair } \\
\text { Good }\end{array}$ & 33 & 62.3 & 20 & 37.7 & 53 & 100 & $(0.438-2.770)$ & \\
\hline Work Period & 7 & 70 & 3 & 30 & 10 & 100 & 1.420 & 0.738 \\
\hline $\begin{array}{l}\text { New } \\
\text { Old }\end{array}$ & 46 & 62.2 & 28 & 37.8 & 74 & 100 & $(0.339-5.945)$ & \\
\hline Infrastructure & 4 & 100 & 0 & 0 & 4 & 100 & 1.633 & 0.292 \\
\hline $\begin{array}{l}\text { Insufficient } \\
\text { Adequate }\end{array}$ & 49 & 61.3 & 31 & 38.3 & 80 & 100 & $(1.372-1.944)$ & \\
\hline Skin condition & 8 & 57.1 & 6 & 42.9 & 14 & 100 & 0.741 & 0.840 \\
\hline $\begin{array}{l}\text { Sensitive } \\
\text { Not Sensitive }\end{array}$ & 45 & 64.3 & 25 & 37.5 & 70 & 100 & $(0.231-2.377)$ & \\
\hline Education & 43 & 68.3 & 20 & 31.7 & 63 & 100 & - & 0.042 \\
\hline Vocational Degree & 1 & 16.7 & 5 & 83.3 & 6 & 100 & & \\
\hline Academic Degree & 9 & 60 & 6 & 40 & 15 & 100 & & \\
\hline Professional Degree & & & & & & & & \\
\hline Employment Status & 36 & 57.1 & 27 & 42.9 & 63 & 100 & 0.314 & 0.09 \\
\hline $\begin{array}{l}\text { Civil Servant } \\
\text { Contract }\end{array}$ & 17 & 81 & 4 & 19 & 21 & 100 & $(0.95-1.040)$ & \\
\hline Gender & 9 & 75 & 3 & 25 & 12 & 100 & 1.909 & 0.521 \\
\hline Male & 44 & 61.1 & 28 & 38.9 & 72 & 100 & $(0.476-7.664)$ & \\
\hline Female & & & & & & & & \\
\hline Motivation & 27 & 77.1 & 8 & 22.9 & 35 & 100 & 2.986 & 0.043 \\
\hline Low & 26 & 53.1 & 23 & 46.9 & 49 & 100 & $(1.134-7.861)$ & \\
\hline High & & & & & & & & \\
\hline Type of Room & 7 & 23.3 & 23 & 76.7 & 30 & 100 & - & 0.0001 \\
\hline ICU \& PICU & 25 & 92.6 & 2 & 7.4 & 27 & 100 & & \\
\hline Non-Surgical & 9 & 75 & 3 & 25 & 12 & 100 & & \\
\hline Pediatric & 12 & 80 & 31 & 20 & 15 & 100 & & \\
\hline Surgery Room & & & & & & & & \\
\hline
\end{tabular}

have a significant effect on the co mpliance of nurses' handwashing. The gender of nurses was dominantly females. However, there is no difference in the proportion of compliance with handwashing between female and male respondents. The age of nurses was mostly $\leq 40$ years, but there was found no difference in the proportion of compliance with handwashing between nurses aged $\leq 40$ years and nurses aged $>41$ years. Most of the nurses considered that the handwashing infrastructure was adequate in the patient room, and there was no difference in the proportion of compliance with handwashing among nurses who were considered supported by the infrastructure to be adequate and inadequate. These findings support previous research that found that the availability of facilities and infrastructure did not relate to handwashing compliance (Yotlely, 2019). The researcher assessed the non-correlation because there were adequate handwashing facilities in the 
room. There were hand rubs in each patient's bed, room corridor, and nurse station.

The results showed that most of the nurses had a long working tenure, namely $>5$ years, but there was no difference in the proportion of compliance with handwashing between nurses with a long tenure and nurses with a new tenure. The positive attitude of nurses is almost proportional to negative attitudes, and there is no difference in the proportion of compliance with handwashing between nurses with positive attitudes and nurses with negative attitudes. The same thing is found in the knowledge factor. Most of the nurses have good knowledge of handwashing. However, there is no difference in the proportion of compliance in washing hands between nurses with adequate knowledge and nurses with less knowledge. This is also in line with previous research which found that knowledge was not related to handwashing cosmpliance (Arifin \& Ernawaty, 2019; Ratnasari \& Dulakhir, 2016; Syamsulastri, 2017). Nurses may have good knowledge about handwashing, but other factors can lead to difficulty implementing handwashing compliance, one of which is the high workload. From the research results, nurses in ordinary inpatient rooms (surgical, nonsurgical, children) were the most obedient to wash their hands at moment 3 (after being exposed to body fluids) and moment 4 (after touching the patient). However, the most neglected moment is moment 5 (after touching the patient's environment). It shows that nurses prioritize washing hands after exposure to patients. Further research is needed regarding the workload of nurses in inpatient rooms.

Also, another finding from this study is that employment status does not correlate with nurse handwashing compliance. Most of the nurses are civil servants, but there is no difference in the proportion of compliance in washing hands between nurses who are civil servants and nurses who are honorary status. Also, most skin conditions are not sensitive to handwashing fluids. However, there is found no difference in the proportion of washing hands between nurses with sensitive skin conditions and nurses who are not sensitive to handwashing fluids. There were complaints from the respondent such as dry hands, but the researcher's opinion is that the small number of nurses who have sensitive skin causes this variable to be unrelated. It is necessary to develop further research to find out more clearly.

An interesting finding in this study is that nurses' motivation affects compliance with nurses' handwashing. The number of nurses with high motivation is almost equal to those with low motivation. Nevertheless, there is a difference in the proportion of compliance with handwashing between highly motivated nurses and those with low motivation. These findings support previous research where 'motivation' is significantly related to nurses' compliance with handwashing (Ananingsih \& Rosa, 2016; Fauzi et al., 2015; Sani \& Pratiwi, 2017). Nurses need to cultivate high motivation as a form of dedication and altruism to patients' needs for healing
(Nursalam, 2017). Besides, nurse education was found to affect compliance with handwashing. There was a difference in the proportion of handwashing between nurses with vocational, academic, and professional education. One of the factors that can increase the productivity or performance of nurses is the formal education of nurses. Education provides knowledge not only directly related to the implementation of tasks, but also a foundation for self-development and the ability to utilize all available facilities for smooth tasks (Nursalam, 2017).

The new finding from this study is that room type is related to the compliance of nurses' handwashing. There is a difference in the proportion of compliance with handwashing between intensive and nonintensive rooms (general inpatient care). Based on Table 6, it was found type of room to be the most dominant factor. Of the five rooms studied, there were two types of intensive rooms and three general inpatient rooms. Based on diagram 2, the highest handwashing compliance is in the intensive room, where moments 1 to 4 are $100 \%$, but in moment 5 the compliance is $73.3 \%$. Meanwhile, in general, inpatient rooms, the non-compliance of handwashing was five moments higher. This finding supports previous research that the workplace influences compliance with hand hygiene, where ICU nurses are more obedient than other wards (Arini, 2016). Further research is needed to be able to find a more specific cause.

The researcher's opinion is that not only individual characteristics should be highlighted in compliance with nurses' handwashing. Other factors outside the nurses as individuals also contribute to handwashing compliance. They can be organizational characteristics, which include reward systems, training, and development, leadership, and organization culture. Moreover, it is important to pay attention to aspects of job characteristics, including feedback, workload, and assignment methods.

This study has several limitations, although attempts have been made to overcome them. Researchers could not control nor directly see when respondents filled in answers or justify the truth of the answer given. In addition, observing the compliance of nurses' handwashing was only done once in a period.

\section{CONCLUSION}

Most nurses do not comply handwashing. From 11 nurses' individual characteristic factors, there were three factors related to the compliance of the nurse's hand washing, namely education, motivation and type of patient room. The research found type of room to be the dominant factor. However, knowledge, facilities, attitudes, age, gender, skin sensitivity conditions, and employment status do not relate to handwashing compliance.

It is hoped that nurses can increase selfmotivation to perform the five moments of hand hygiene while working, as a form of dedication at 
work and to protect patients and themselves from nosocomial infections. The researcher also recommends that further researchers be able to identify more about other factors, including reward systems, training and development, leadership, organizational culture, feedback, workload, and assignment methods. Thus, they can find the right intervention to increase compliance with the nurse's handwashing.

\section{ACKNOWLEDGEMENT}

Acknowledgments are presented to the Higher Education Service Institution (LLDIKTI) Region II of the Ministry of Research and Technology who funded this research.

\section{REFERENCES}

Akyol, A. . (2007). Hand Hygiene among nurses in Turkey: opinion adn practices. Journal of Clinical Nursing, 16(3), 431-137.

Ananingsih, P. D., \& Rosa, E. M. (2016). Kepatuhan 5 Moment Hand Hygiene pada Petugas di Laboratorium Klinik Cito Yogyakarta. Jurnal Medicoeticolegal Dan Manajemen Rumah Sakit, 5 (1), 16-24. https://doi.org/10.18196/jmmr.5102

Anugrahwati, R., \& Hakim, N. (2019). Faktor-Faktor yang mempengaruhi Kepatuhan Perawat dalam Melakukan Hand Hygiene Five Moment di RS Hermina Jatinegara. Jurnal Ilmiah Keperawatan Altruistik, 2(1), 41-48.

Arifin, A., \& Ernawaty, J. (2019). Faktor-faktor yang berhubungan dengan kepatuhan hand hygiene mahasiswa profesi ners di ruangan rawat inap. Jurnal Kesehatan, 100-113.

Arini, M. (2016). Health Belief Model Pada Kepatuhan Hand Hygiene Di Bangsal Berisiko Tinggi Healthcare Acquired Infections (Hais) (Studi Kasus Pada Rs X). Jurnal Medicoeticolegal Dan Manajemen Rumah Sakit, 5(2), 129-135. https://doi.org/10.18196/jmmr.5117

Cassini, A., Plachouras, D., Eckmanns, T., Abu Sin, M., Blank, H. P., \& Ducomble, T., Suetens, C. (2016). Burden of six healthcare- associated infections on European population health: Estimating incidence-based disability-adjusted life years through a population prevalence-based modelling study. PLoS Medicine, 13 (10).

Duerink, D. ., Farida, H., Nagelkerke, N. J. ., Wahyono, H., Keuter, M., Lestari, E. ., Hadi, U., \& Van den Broek, P. . (2006). Preventing Nosocomial Infection: Improving Compliance with Standard Precautions In An Indonesia Teaching Hospital. Journal of Hospital Infection, 64(1), 36-43.

Fauzi, N., Ahsan, \& Azzuhri, M. (2015). Pengaruh Faktor Individu, Organisasi dan Perilaku terhadap Kepatuhan Perawat dalam Melaksanakan Hand Hygiene di Ruang Rawat Inap Rumah Sakit Tk. II Dr. Soepraoen Malang. Jurnal Aplikasi Manajemen, 13(4), 566-574.

Hugonnet, S., Perneger, T. ., \& D, P. (2002). Alcohol- based handrub improves compliance with hand hygiene in intensive care units. Archives of Internal Medicine, 162, 1037-1043.

Jonker, C., \& Othman, M. (2018). Hand Hygiene among Hospital Staff: A Survey of Knowledge, Attitude, and Practice in A General Hospital in Syria. Jurnal Keperawatan Indonesia, 21(3), 139-149. https://doi.org/10.7454/jki.v21i3.513

Kampf, G., Löffler, H., \& Gastmeier, P. (2009). Hand hygiene for the prevention of nosocomial infections. Deutsches Arzteblatt International, 106(40), 649-655.

Karuru, C. P., Mogi, T. I., \& Sengkey, L. (2016). Gambaran Kepatuhan Tenaga Kesehatan Dalam Menerapkan Hand Hygiene Di Rawat Inap Rsup Prof. Dr. R D. Kandou Manado. E-CliniC, 4(1), 2-5. https://doi.org/10.35790/ecl.4.1.2016.10942

Lankford, M. ., Zembower, T. ., Trick, W. ., Hacek, D. ., Noskin, G. ., \& Peterson, L. . (2003). Influence of Role Model and Hospital Design on the Hand Hygiene of Health-Care Worker. Emerging Infectious Disesase, 9(2), 217.

Nurbaety, Baharuddin, A., Amelia, A. R., \& Julianti, S. (2019). Penerapan Standar Prosedur Operasional (SOP) Hand Hygiene Pada Tenaga Kesehatan di Instalasi Rawat Inap Rumah Sakit Dr. Tadjuddin Chalid Kota Makasar. Prosiding Seminar NAsional, 2.

Nursalam. (2011). Manajemen Keperawatan Aplikasi dalam Praktik Keperawatan Profesional (3rd ed.). Salemba Medika.

Nursalam. (2017). Metodologi Penelitian Ilmu Keperawatan: Pendekatan Praktis (P. Puji Lestasi (ed.); 4th ed.). Salemba Medika.

Petersen, M. ., Holm, M. ., Pedersen, S. ., Lassen, A. ., \& Pedersen, C. (2010). Incidence and Prevalence of Hospital-Acquired Infection in a Cohort of Patients Admitted to Medical Departments. Danish Medical Bulletin, 57(11), A4210-A.

Pratama, B. S., Koeswo, M., \& Hariyanti, T. (2016). Pengaruh Kelengkapan Handrub \& Poster terhadap Kemauan Perawat untuk Berubah Terkait Hand Hygiene pada Rawat Inap RS Ananda Blitar. Jurnal Aplikasi Manajemen, 14(4), 757-766. https://doi.org/10.18202/jam23026332.14.4.16

Putri, V. S., Yusuf, A., Tristiana, R. D., Nursing, F., \& Airlangga, U. (2018). Analysis of Factors Related to Nursing Student Self Wareness in Doing Screening for Psychosocial Problems. 15(3).

Ratnasari, D., \& Dulakhir. (2016). Faktor-Faktor Yang Berhubungan Dengan Kepatuhan Perawat Ruang Rawat Inap Dalam Pelaksanaan Hand Hygiene Di Rumah Sakit Anna Medika Kota Bekasi Tahun 2016. Jurnal Ilmiah Kesehatan, 8.

Saito, H., Kilpatrick, C., \& Pittet, D. (2018). The 2018 World Health Organization SAVE LIVES: Clean Your Hands Campaign targets sepsis in health care. Intensive Care Medicine, 44, 499-501.

Sani, F. N., \& Pratiwi, M. R. (2017). Hubungan Motivasi Perawat Dengan Tingkat Kepatuhan Melakukan Cuci Tangan Di Rsi Klaten. Profesi (Profesional Islam): Media Publikasi Penelitian, 14(2), 11. 
https://doi.org/10.26576/profesi.146

Sickbert-Bennett, E. E., Dibiase, L. M., Schade Willis, T. M., Wolak, E. S., Weber, D. J., \& Rutala, W. A. (2016). Reduction of healthcare- associated infections by exceeding high compliance with hand hygiene practices. Emerging Infectious Diseases, 22(9), 1628-1630.

Syamsulastri. (2017). Faktor yang Berhubungan dengan Kepatuhan Perawat dalam Melakukan Hand Hygiene. Respirstory Unmuhpkn.

Umboh, F. ., Doda, D. ., \& Kandau, G. . (2017). Analisis Faktor-Faktor yang Berhubungan dengan Kepatuhan Perawat MElaksanakan Hand Hygiene dalam Mencegah Infeksi Nosokomial di Ruang Rawat Inap Rumah Sakit Advent Manado.

von Lengerke, T., Lutze, B., Krauth, C., Lange, K., Stahmeyer, J. T., \& Chaberny, I. F. (2017). Promoting hand hygiene compliance. Deutsches Arzteblatt International, 114(3), 29-36.

WHO. (2009). Guide to Implementation: A Guide to Implementation of the WHO Multimodal Hand Hygiene Improvement Strategy.

Yotlely, A, S. (2019). Analisis Faktor yang Berhubungan dengan Kepatuhan Perawat dalam Penerapan Kewaspadaan Standar di RSUD Piru Penelitian Korelasional. Repository Unair. 